\title{
Development of Blended Learning-Based Learning Tools to Improve Mathematical Creativity Ability and Self-Efficacy of High School Students
}

\author{
Ade Irwansah Nasution, Izwita Dewi, Dian Armanto \\ Mathematics Education, Postgraduate School, State University of Medan \\ Medan, North Sumatra, Indonesia \\ *Corresponding autho: adeirwansah35@yahoo.com
}

\begin{abstract}
This study aims to: 1) find out how the validity, practicality, and effectiveness of Blended learning-based learning tools in mathematics learning; 2) knowing the improvement of students' mathematical creativity skills using Blended learning-based devices in mathematics learning; and 3) knowing the increase in students' self-efficacy by using learning tools based on Blended learning in learning mathematics. This type of research is a type of development research. This study uses a 4-D development model (define, design, develop, and disseminate) Thiagarajan and Semmel (1974) by developing a tool based on Blended Learning. This research will be carried out at Al-Ulum Terpadu Islamic High School Medan. The subjects in this study were students of SMA Islam AlUlum Terpadu Medan grade 11 MIA for the academic year 2021/2022. The results showed that: 1) Blended Learning-based learning tools in improving students' mathematical creativity and learning abilities that were developed had met the valid, practical and effective criteria; 2) The improvement of students' mathematical creativity skills using tools that have been developed based on Blended Learning seen from the N-Gain 0.83 which means it is in the "High" category; 3) Increasing students' self-efficacy using tools that have been developed based on Blended Learning seen from the N-Gain Value of 0.14 means that they are in the "Low" category or only slightly increased their Self-efficacy abilities.
\end{abstract}

Keywords: Development of Learning Devices, Blended Learning, Mathematical Creativity Ability, Student SelfEfficacy

DOI: $10.7176 / \mathrm{JEP} / 13-5-02$

Publication date: February $28^{\text {th }} 2022$

\section{INTRODUCTION}

Mathematics is a universal science that underlies the development of modern technology today. Sumartini (2016) argues that mathematics has an important role as a means of solving life's problems. . The importance of mathematics in learning starting from elementary school to college level which functions in developing reasoning power of thinking ability. The importance of learning mathematics is not in line with the desire of students to learn mathematics because most students think that mathematics is a difficult subject and as a lesson in memorizing formulas, therefore students' understanding of mathematical concepts is very lacking, besides that the teacher's task as a teacher is not able to prepare mathematical plans so that the mathematics material cannot be accepted by students. The learning process will run well if the teacher is able to design learning well, starting from planning learning tools, carrying out classroom learning, to evaluating. In carrying out this main task, the teacher experiences obstacles, even obstacles in making learning tools, carrying out classroom learning and evaluating them.

Making learning tools is a must that must be owned by every teacher, because in making learning tools it contains important aspects in the teaching and learning process. These aspects are for example the competencies to be achieved, how to achieve the material or subject matter, interaction models, evaluation models and so on. According to Nur (in Sulistyaningsih, 2013: 2) that learning tools provide convenience and can assist teachers in preparing to carry out teaching and learning activities in the classroom, so that with the right learning tools it can make it easier for students to learn mathematics.

Researchers also carried out observations on July 7, 2020 in junior high and high school schools at the AlUlum Terpadu Islamic college in Medan. The evidence in the field shows facts that are not as expected, where teachers do not develop their own learning tools, this is evident from findings in the field that documents The learning tools that the teacher has are incomplete when checked in the curriculum section.

A professional teacher must have the ability and skills to compile and develop learning tools that will be used in learning activities in the classroom (Chodijah, 2012). The learning tools developed must be adapted to the curriculum used and adapted to the needs of students in the classroom, namely syllabus, lesson plans, teaching materials, LKPD, learning media, and assessment of learning outcomes. This learning device will be used by the teacher as a guide in learning activities so that learning will take place in a directed manner in accordance with the learning objectives and indicators that must be achieved so that feedback is expected in the form of optimal student 
learning outcomes.

In addition to the difficulties of teachers in developing learning tools, it can also be seen from the mathematics books used by students in learning, namely the problems and math problems in students' mathematics books, not all students are invited to think at a higher level, only the subject matter and not related. with other fields of science so that it results in the low ability of students' mathematical creativity.

The creativity difficulties experienced by students are caused because mathematics is considered as a formula for memorizing lessons, therefore students' understanding of mathematical concepts is very lacking, the results of tests conducted by researchers on July 8, 2020 to several students of SMA Islam Al-Ulum Terpadu Medan showed several answers. In general, students can be grouped: (1) Students do not think about the answers according to what they think (Original thinking). (2) Students are not able to think fluently because they do not understand the concept well (fluency thinking). (3) Students are not able to develop their thinking because of the lack of basic concepts (Flexibilty thinking). (4) Students are not able to understand the questions more deeply so they cannot develop answers properly (elaborative thinking). From the findings above, according to Turkemen (2015) it is the criteria for students who are not creative in thinking mathematically.

Creativity is needed in the world of education according to what Erson (2013) said. Education is tasked with training individuals to be confident, curious, creative, innovative and also able to understand the differences in how to pay attention to students who have these characteristics. One's creativity also has an effect on learning achievement in mathematics at school, because students with high creativity also encourage their learning achievement. Thus, it can be interpreted that for creative students, mathematics has a different impression. Mathematics can be used as a challenge and an opportunity to be creative. It can also be interpreted that creativity determines the achievement of optimal mathematics learning abilities, and is able to achieve high achievements in learning mathematics.

According to Komarudin (2015) Creative thinking skills are needed in the world of work. Individual characteristics needed in the world of work are individuals who have attitudes, master basic skills, master thinking skills, and master interpersonal skills. Self-confidence and motivation to excel are examples of must-have attitudes, while examples of basic skills are reading, writing, listening, speaking, and using computers. To improve students' creative thinking, it is necessary to use supportive learning tools and supportive learning media such as Blended learning-based learning tools, with this learning model it is hoped that it will improve students' abilities, especially students' creative abilities. This requires teachers to be more creative and innovative in carrying out the learning process the teacher seeks to form appropriate learning tools and learning models and apply them to students.

According to Cheung \& Hew, (2011) the Blended learning model can improve student learning outcomes and to overcome learning problems. (Octaria, 2020) the learning system in Blended learning is flexible because students can control learning activities according to time, place, path and pace so that students have more opportunities to interact with teachers and students during the learning process in class. Blended learning is an effective combination with various learning models and learning styles that can be applied to an interactive online (e-learning) and conventional (face-to-face) learning environment. Blended learning model can be implemented in all fields of science including mathematics. Blended learning not only provides more experience for students but also has several other advantages such as increasing student access and ease of accessing learning materials, increasing the quality of learning and reducing learning costs (Stein \& Graham, 2014:14).

In accordance with Bandura's opinion, mathematics is also related to other sciences, for that creativity is needed by studying and understanding mathematical concepts that can lead to trust and confidence in each individual to produce something (Self-efficacy). This belief will move individuals to behave more diligently, tenaciously and bravely to face problems in accordance with their opinion (Mukhid 2009: 5) Strong feelings of efficacy increase one's skills and well-being in unimaginable ways.

Responding to the above problems, blended learning is needed because it can increase students' creativity and self-efficacy, so the authors are interested in conducting a study entitled "Development of Blended Learning-Based Learning Devices to Improve Mathematical Creativity Ability and Self-Efficacy of High School Students".

\section{METHOD}

\section{Research Pattern}

This research is categorized into the type of development research. This study uses a 4-D development model (define, design, develop, and disseminate) Thiagarajan and Semmel (1974) by developing a tool based on Blended Learning.

\section{Subject and Object}

The subjects in this study were students of SMA Islam Al-Ulum Terpadu Medan grade 11 MIA for the academic year 2021/2022, while the objects in this study were learning tools based on Blended Learning. 


\section{Prosedur penelitian}

The learning device development procedure in this study refers to the 4D (four-D) development model. According to Thiagarajan (1974) the 4D research and development model consists of 4 main stages, namely define, design, develop, and disseminate.

1) Define

The analysis of students in this study is a study of the characteristics of the students of SMA Islam Al-Ulum Integrated Medan in accordance with the design and development of the material. These characteristics include the background of academic ability (knowledge) of cognitive development, as well as individual or social skills related to the chosen learning topic, media, format and language. Student analysis is carried out to obtain a description of the student's characteristics, including: (1) the level of ability or intellectual development (2) individual or social skills that are already possessed and can be developed to achieve the set learning objectives.

\section{2) Design}

The design stage aims to design learning devices. There are four steps in this stage:

a) Constructing criterion- referenced test

b) Media selection

c) Format selection

d) Initial design

\section{3) Develop}

This development stage is carried out by researchers to analyze, test, develop, evaluate and revise the designed learning tools. There are two steps taken at this stage, namely: :

a) Validation of expert judgment

Validation of learning tools is carried out to determine the feasibility of learning devices, validation is carried out by several experts. The expert in question is a validator who is competent to assess learning and provide input or suggestions to improve the learning tools that have been made.

The expert's assessment includes content validation which includes all learning tools that have been developed at the design stage of draft I, so as to produce draft II that is suitable for use. The results of the validation of the experts are used as the basis for revising and improving learning tools and instruments. In general, validation includes: Format, language, illustrations, content (material) and learning objectives.

b) Field trial

The trial design used in this study is a one shot case study or also known as a one group posttest-only design. The data obtained from the results of the first trial were analyzed and used as a reference for revision of the learning device for the next trial until it was concluded that the effective criteria had been met. At each stage of the trial, the necessary data will be recorded, namely how the students' creativity abilities, how students respond during learning, how to increase students' mathematical creativity abilities and self-efficacy from the first trial and subsequent trials. At the end of the trial, the final draft will be obtained.

\section{4) Disseminate}

This form of dissemination is intended to obtain input, corrections, suggestions, assessments, to improve the final product development so that it is ready for adoption by product users. The dissemination stage is intended to socialize learning t ools that have been tested. This activity is limited to teachers and students and is only carried out at the school where the researcher conducts research, namely the Al-Ulum Terpadu Islamic High School Medan.

\section{Instruments}

According to Aker (1999) the learning device developed is said to be of quality if it meets three categories, namely validity, practicality, and effectiveness. To measure the learning tools developed, a research instrument was compiled and developed. The instrument developed in the trial is described as follows.

1) Learning Tool Validation Instruments

The validation of learning tools is used to obtain data about the quality of learning tools based on the assessment of experts. Validation sheet for Learning Implementation Plan (RPP), Teacher's Manual (BPG), Student Book (BS) and Student Activity Sheet (LKPD).

\section{2) Creative Thinking Ability Test}

The tool used to collect data to determine the level of students' mathematical creative thinking is a description test which begins with compiling a grid of questions based on predetermined variables and indicators. 3) Self-efficacy questionnaire

This instrument is useful for capturing student self-efficacy data. The form of this instrument is a questionnaire consisting of 30 questions. The scoring technique for the instrument uses a Likert scale.

\section{4) Practicality Assessment Instrument}

To test the practicality, it can be seen from how students respond to learning and observing the teacher's ability to manage learning using the developed device. 


\section{5) Effectiveness Assessment Instrument}

The effectiveness of learning tools related to creative abilities is determined based on the classical achievement of students' mastery. The data obtained from the posttest results of students' mathematical creativity abilities in each trial. Individual student learning completeness is done by calculating student scores. While learning completeness per class or the percentage of classical completeness (PKK) is obtained by calculating the percentage of the number of students who have completed individually a class is said to have completed learning if the PKK is $85 \%$ (Trianto, 2011). If these criteria have not been met, it is necessary to review the process and learning outcomes to obtain effective learning tools.

\section{Increasing students' mathematical creativity and self-efficacy}

For the large increase in mathematical creativity and self-efficacy, it will be seen through the results of the N-gain calculation from the pre-test of mathematical creativity and self-efficacy after carrying out learning with good quality tools including validity, practicality, and effectiveness. The magnitude of the increase is calculated using the normalized $\mathrm{N}$-gain formula.

$$
N-\text { Gain ternormalisasi }(g)=\frac{\text { Posttest Score }- \text { Pretest Score }}{\text { Maximum Score }- \text { Pretest Score }}
$$

Gery (dalam Bao, 2006)

The results of the normalized $\mathrm{N}$-gain calculation are then interpreted using the following classification:

Table 1. Classification of Normalized N-gain

\begin{tabular}{|c|l|}
\hline $\boldsymbol{N}$-Gain (g) Score & Interpretation \\
\hline$g \geq 0,7$ & High \\
\hline $0,3 \leq g<0,7$ & Medium \\
\hline$g<0,3$ & Low \\
\hline
\end{tabular}

Hake (1999)

\section{RESULTS AND DISCUSSION}

Learning Tool Validation Results

Analysis of the validity of the mathematics learning media assisted by Macromedia Flash that was Validation is an important part in developing tools to improve the weaknesses of learning tools. The validators selected in this study consisted of three experts and two high school teachers. The results of the validator can be seen in the attachment of each learning device. The results of the calculation of the average learning device validation score can be seen in Table 2 .

Table 2. Results of Calculation of the Average Score Validation of Learning Devices

\begin{tabular}{|l|l|l|}
\hline & Average & Category \\
\hline RPP & 4,09 & Valid \\
\hline LKPD & 4,13 & Valid \\
\hline Teacher's Books & 4,05 & Valid \\
\hline Student Books & 4,16 & Valid \\
\hline
\end{tabular}

From Table 2. it can be seen that the total average value for the results of the validation of the RPP, LKPD, teacher's book and student's book is 4.09, 4.13, 4.05 and 4.16, respectively. So by referring to these criteria, it can be concluded that the learning implementation plan, LKPD, teacher's books and student books developed with blended learning-based learning tools meet the validity criteria with valid categories.

\section{Practicality of Learning Devices}

One of the criteria for practical learning tools is seen from how students respond to learning using the developed tools. The criteria are met if the number of students who give a positive response is greater or $80 \%$ of the many subjects studied. Based on the results of the analysis of student responses to learning using the developed device, the average positive response was $84.45 \%$. In other words, the student's response to learning has met the predetermined criteria. Student responses to learning using learning that have been developed for each aspect are $83.84 \%, 86.64 \%, 90.9 \%, 84.09 \%$. Based on these results, all aspects meet the criteria, namely the positive response aspect to be interested in participating in further learning such as the learning they are currently participating in.

The next practical criterion is the teacher's ability to manage learning using the tools that have been developed. The device is said to be practical if the device that has been developed can be used properly by the teacher. The criteria that must be met for the teacher's ability to manage learning so that it is said to be successful, the ability score is in the "good" category or at least 3.50.

Based on the results of the analysis of the teacher's ability to manage learning using observation sheets, the overall average value was 3.74 and was in the "good" category. The results of observations of 4 aspects of the ability of teachers to manage learning are $3.50,3.33,4.00,3.75,4.16$, respectively. Based on this value, there is 1 
aspect that does not meet the practical criteria, namely the aspect of the acquisition of information, then for other aspects that have met the practical criteria.

\section{Effectiveness of Learning Tools}

From the 4 valid questions, the results of the students' mathematical creativity ability test results in trial 1 as in Appendix 18. From the results of the students' mathematical creativity ability tests in trial 1, the classification of students' creative abilities is presented in table 3.

Table 3. Completeness of Students' Mathematical Creativity Ability Test on Trial 1

\begin{tabular}{|l|c|c|}
\hline \multicolumn{1}{|c|}{ Category } & The number of students & Percentage \\
\hline Complete & 23 & $65 \%$ \\
\hline Not Complete & 12 & $25 \%$ \\
\hline
\end{tabular}

From table 3. it can be seen that there are 23 students who complete or $65 \%$, while the percentage of students who do not complete is 12 people or $25 \%$. Based on the criteria for devices that are said to be effective, the learning tools used in trial 1 have not been effective. This is because the students' mathematical creativity ability has not met the predetermined criteria.

Then from the results of the post-test of the mathematical creativity ability of trial 2 , the classification of creativity abilities is obtained which is presented in table 4.

Table 4. Completeness of Students' Mathematical Creativity Ability Test on Trial 2

\begin{tabular}{|l|c|c|}
\hline \multicolumn{1}{|c|}{ Category } & The number of students & Percentage \\
\hline Complete & 36 & $100 \%$ \\
\hline Not Complete & 0 & $0 \%$ \\
\hline
\end{tabular}

From table 4. it can be seen that the students who complete are $100 \%$, while the percentage of students who do not complete is $0 \%$. In trial 2 , the post-test of mathematical creativity ability showed that all students were complete, namely 36 people $(100 \%)$. It was concluded that the students' mathematical creativity ability had met the predetermined criteria. Based on the criteria for the devices that have been said to be effective, the learning tools used in trial 1 are already effective. This is because students' mathematical creativity abilities have met the specified criteria.

\section{Increasing Students' Mathematical Creativity Ability}

After the learning tools can be said to be of good quality including valid, practical, and effective, it will be seen the increase in students' mathematical creativity skills using Blended learning-based learning tools. Improvements will be seen through N-Gain. From the results of the pre-test and post-test of the students' mathematical creativity abilities in the 2 nd trial. The results of the N-Gain of students' mathematical creativity abilities are presented in table 5 .

Table 5. Results of N-Gain Students' Mathematical Creativity Ability

\begin{tabular}{|c|c|c|}
\hline -Gain $(g)$ Score & Interpretation & The number of students \\
\hline$g \geq 0,7$ & High & 19 \\
\hline $0,3 \leq g<0,7$ & Medium & 6 \\
\hline$g<0,3$ & Low & 1 \\
\hline
\end{tabular}

Based on table 4.22 it can be seen that 19 students got an N-Gain score in the range of 0.7 or experienced an increase in creativity in the "High" category. For students who experienced an increase in the "medium" category or got an N-Gain score at an interval of $0.3 \leq \mathrm{g} \leq 0.7$, there were 6 and 1 student who experienced an increase in mathematical creativity in the "Low" category. While the total post-test score of students' mathematical creativity abilities is 2,425 , based on this value, it can be seen that the N-Gain of mathematical creativity abilities is as follows:

$$
\text { Gain ternormalisasi }(g)=\frac{\text { Post-test Score-Pretest Score }}{\text { Maximum Score-Pretesst Score }}=\frac{2.425-1.565}{2.600-1.565}=0,83
$$

The N-Gain value is 0.83 if it is presented into the classification described in Chapter III, then the total increase in creativity ability obtained is in the "High" category. This means that the learning tools developed and have increased the ability of mathematical creativity with a large increase are in the "High" category, namely with an N-Gain of 0.83 .

This increase is in line with this opinion, it can be understood that with the thought of expanding the situation properly and detailing it in detail about the problems presented, it is very necessary to make it easier for students to understand the concept of the material, especially in learning to improve mathematical creativity abilities. Furthermore, it can be understood that this aspect has a great contribution to the improvement of creative ability so that it is natural to increase it more than other aspects.

This is in line with the opinion of Ambarwari et al (2015: 182) which states that the Blended learning model is an appropriate learning alternative to increase mathematical creativity. It was further explained that Blended 
learning can generate creativity in physical and mental activities, such as practicing theory, discussing, making a work as a result of practicing the results both orally and in writing.

\section{Increasing Student Learning Self-efficacy}

The results of the N-Gain for increasing learning self-efficacy in full can be seen in appendix 31 . In appendix 31 it can be seen that the total score of the student learning self-efficacy questionnaire in trial 1 is 2,077 out of a score of 330. While the total score of the learning self-efficacy questionnaire students in trial 2 was 2,676. Based on this value, it can be seen that the N-Gain of creativity ability is as follows:

Gain ternormalisasi $(\mathrm{g})=\frac{U j i \text { coba } 2 \text { Score }-U j i \text { coba } 1 \text { Score }}{\text { Maximum Score-Uji coba } 1 \text { Score }}$

$$
\begin{aligned}
& =\frac{3089-2915}{4080-2915} \\
& =\frac{174}{1165} \\
& =0,14
\end{aligned}
$$

The N-Gain value of 0.14 if interpreted into the classification described in Chapter III, then the total increase in creativity obtained is in the "Low" category. This means that the device to increase students' creativity by learning large improvements is in the "Low" category, namely with an N-Gain value of 0.14.

\section{CONCLUSION}

Blended Learning-based learning tools in improving students' mathematical creativity and learning abilities that have been developed have met the valid criteria, namely for the Learning Device Plan (RPP) and Student Worksheet (LKPD) covering aspects of the appropriateness of format, language and content with a total score of each of which is 4.09 and 4.13 or both are in the "Valid" category, while for the teacher's book and student's book it covers aspects of the appropriateness of format, language, content, and presentation and graphics with a total score of 4.05 and 4.16 and is in the " valid" too.

Blended Learning-based learning tools in improving students' mathematical creativity and student learning that have been developed have been practically used, namely they have met the practical criteria because they can be used properly, which is shown through the teacher's ability sheet to manage learning and has received a good response. The average total score of the teacher's ability to manage learning is 4.19 or in the "Good" category with the abilities of each aspect of each being 4.00, 4.30, 4.00, 4.35, and 4.30 or all of them are in the "Good" category as well. As for student responses, the final total percentage of positive responses on average is $92.74 \%$ with the response values of each aspect being $96.38 \%, 92.74 \%, 90.9 \%, 93.2 \%$ and $95.5 \%$.

Blended Learning-based learning tools in improving students' mathematical creativity and student learning that have been developed have been effective to use because they have met the criteria for mastery learning as seen from the mathematical creativity ability test, which shows that $100 \%$ of students classically complete the specified individual targets.

The improvement of students' mathematical creativity skills using tools that have been developed based on Blended Learning seen from the N-Gain 0.83 means that they are in the "High" category with details of 19 students getting an N-Gain score 0.7 or experiencing an increase in the creativity ability of students in the "High" category." and 6 students got an N-Gain score at intervals of $0.3 \mathrm{~g}<0.7$ or experienced an increase in creativity ability in the "Medium" category, and 1 student got an N-Gain score $g<0.3$ or in the "Low" category.

Increasing students' self-efficacy using tools that have been developed based on Blended Learning seen from the N-Gain Value of 0.14 means that they are in the "Low" category or only experienced a slight increase in Selfefficacy abilities".

\section{REFERENCES}

Aker, J.V.D. 1999. Principles and Methods of Development Research. Dalam Plomp, T; Nieveen, N; Gustafson, K; Branch, R.M; dan van den Akker, J (eds). Design Approaches and Tools in Education and Training. London: Kluwer Academic Publisher.

Bao, L. 2006. Theoritucal Comparisons of Average Normalized Gain Calculations.

Department of Physics, the Ohio State University: Physiscs Education Research. AM. J. Phys., Vol. 74, No. 10, October 2006.

Cheung, W. S. \& Hew, K. F. (2011). Design and evaluation of two blended learning approaches: Lessons learned. Australasian Journal of Educational Technology, 27(Special issue, 8), 1319-1337. http://www.ascilite.org.au/ajet/ajet27/cheung.html

Chodijah, S., Fauzi, A., \& Ratnawulan, R. (2012). Pengembangan Perangkat Pembelajaran Fisika menggunakan Model Guided Inquiry yang dilengkapi Penilaian Portofolio pada Materi Gerak Melingkar. Jurnal Penelitian Pembelajaran Fisika, 1(1), 1-19. Retrieved from http://ejournal.unp.ac.id/index.php/jppf/article/view/603

Erson, E \& Baser,E. 2013. The Effect Of Problem-based learning method in higher education on creative thinking. 
Procedia - Social and Behavioral Sciences. Vol 1163494 - 3498 ( 2014 ).

Hake, R. (1999). Analyzing Change/Gain Scores. Dept. of Physcis, Indiana University.

Komarudin., dkk. 2015. Perbandingan Berpikir Kritis antara Cooperative Script dan Bertukar Pasangan Memperhatikan Konsep Diri. Ilmu Pendidikan Indonesia, 2 (2), Hlm: 1-11. Tersedia di garuda dikti.go.id. Diunduh tanggal 4 Oktober 2017.

Mukhid, A. 2009. Self-Efficacy (Perspektif teori Kognitif sosial dan Implikasinya terhadap Pendidikan. Tadrîs. Volume 4. Nomor 1. 2009

Octaria, D., Fitriasari, P., Sari, N. 2020. Blended Learning dengan Macromedia Flash untuk Melatih Kemandirian Belajar Mahasiswa. Jurnal Elemen. Vol 6, No 1. DOI: https://doi.org/10.29408/jel.v6i1.1596

Sulistiyaningsih, D. Dan Marwasari, V.D. 2015. Keefektifan Model Pembelajaran Kooperatif Tipe Team Assited Indivudualizattion Berbasis Kontruktuvisme untuk Meningkatkan Kemampuan Kreatif. JKPM; VOLUME 2 NOMOR 1, APRIL 2015

Stein, Jared \& Graham, (2014). Essentials for Blended Learning: A Standards-Based Guide. New York: Routledge. Sumartini, T. S. 2016. Peningkatan Kemampuan Pemecahan Masalah Matematis Siswa melalui Pembelajaran Berbasis Masalah. Jurnal Pendidikan Matematika STKIP Garut. V Volume 5, Nomor 2, Mei 2016

Thiagarajan, S., Semmel, Ds., Semmel, M. 1974. Intructional Development For Training Teachers Of Exceptional Children. A Source Book Blomingtn, Central For Innovation On Tesching The Handicapped

Trianto. (2011). Mendesain Model Pembelajaran Inovatif - Progresif. Prestasi Pustaka

Turkemen, H. 2015. Creative Thinking Skills Analyzes Of Vocational High School Students. Journal Of Educational And Instructional Studies In The World. Vol : 5 Issue: 1 Article: 10 ISSN: 2146-7463. 